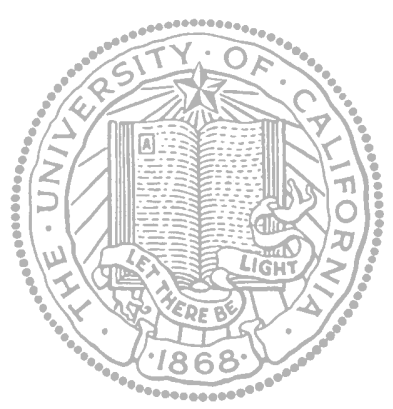

\section{UNIVERSITY OF} CALIFORNIA

Division of Agriculture and Natural Resources

\title{
Budding and Grafting Citrus and Avocados in the Home Garden
}

\author{
PAM ELAM \\ University of California Cooperative Extension Farm Advisor, Fresno County
}

I $\mathrm{t}$ is often tempting, after eating a particularly good orange or avocado, to plant the seed and grow your own tree full of these delicious fruit. Trees grown from these seed, however, may produce fruit that are not edible at all, or the trees may not bear fruit for many years. The best way to produce good-quality fruit is to grow seedlings from them and then attach, by budding or grafting, material from trees that are known to be good producers. Budding and grafting can also be used to change or add varieties to mature citrus or avocado trees, a process known as top working.

This publication is a brief introduction to budding and grafting for the home gardener. For more information, consult the materials listed at the end of this publication or contact your local Cooperative Extension office.

\section{ESTABLISHING SEEDLINGS}

The best time of year to start citrus or avocado seedlings is in early spring. To germinate citrus or avocado seed, plant them in a shallow container such as a nursery flat or a pan with drainage holes in well-drained commercial potting mix. Plant the seed two to three times deeper than their length. For example, a citrus seed about $1 / 4$ inch $\left(6 \mathrm{~mm}\right.$ ) long should be planted about $1 / 2$ to $\frac{3}{4}$ inch (12 to $18 \mathrm{~mm}$ ) deep. Keep the seed in a warm place-between $70^{\circ}$ and $80^{\circ} \mathrm{F}\left(21^{\circ}\right.$ to $\left.27^{\circ} \mathrm{C}\right)$ - and keep the soil moist. Covering the nursery flats with clear glass or plastic will help maintain the proper humidity. Avocado seed can also be germinated by suspending them in water. Place toothpicks horizontally into the seed near the top. Suspend the wide end of the seed in a small container of water with the toothpicks resting on the edge of the container. Place it in indirect light and refresh the water at least weekly.

After germination (usually 12 to 15 days), replant the seedlings into a larger container of good-quality commercial potting mix. (If all danger of frost has passed, the seedlings may be planted directly into the ground where you want the tree to grow instead of replanted into containers.) Good choices for containers include a cardboard milk carton cut horizontally in half or a one-gallon can. Punch drain holes in the bottom of the container. The seedling will be ready for budding or grafting when it has grown to 24 to 30 inches $(60$ to $75 \mathrm{~cm}$ ) tall.

\section{KEYS TO BUDDING AND GRAFTING}

Budding and grafting are vegetative propagation techniques in which a single bud or stem (scion) of a desired plant (cultivar) is attached to a rootstock plant. In budding, a single bud with its accompanying bark (often referred to as budwood) is used as the scion. In grafting, part of a stem or branch is used as the scion.

One of the most important keys to successful budding and grafting is properly positioning the scion on the rootstock. In order for the scion and rootstock to grow 
together, the thin greenish plant layer (cambium) just under the bark of the scion and rootstock must be aligned so that they touch each other. If they do not touch each other, the bud or graft will fail. Within 10 to 15 days, a successful bud or graft forms a hard whitish tissue (callus) where the two cambium layers grow together.

Always use sharp cutting or grafting instruments and make clean, even cuts. Options include a budding knife, a sharp kitchen knife, or a single-sided razor blade. Do not allow the cut surfaces of the scion or rootstock to dry out: immerse cut scions in a pail of water, wrap them in plastic, or graft them immediately after cutting. Also, remove any leaves from scions after cutting to help keep the scions from losing water. Keep the scions in a cool place during the work.

\section{WHEN TO BUD OR GRAFT}

Budding and grafting are best done in the spring or fall when the bark is easily separated from the wood. It should be timed to be early enough so that warm weather will help ensure a good bud union, yet late enough so that the bud will not begin to grow and callus will not grow over the bud itself. Citrus budded or grafted in the fall must be protected from frost. Avocados are best grafted in the spring when the bark is easily separated from the wood.

\section{B U D D I N G}

WARNING: It is against California law to bring citrus budwood into the San Joaquin Valley from any area outside the valley. This law protects commercial citrus groves from disease caused by the Tristeza virus. Budwood or scion wood should be collected only from citrus that has been tested in the last year and found to be free of Tristeza virus. Consult your local county Cooperative Extension office for more details.
Budding is the standard method used to propagate citrus. Aside from being the easiest method, it allows a large number of plants to be propagated from a small amount of scion wood and is suitable for trees, rootstocks, or branches from $1 / 4$ to 1 inch $(0.6$ to $2.5 \mathrm{~cm}$ ) in diameter.

Budwood should be taken only from high-producing, disease-free trees (see sidebar). The best citrus budwood is located just below the most recent flush of new growth; the best avocado budwood is located near the terminal end of shoots that have fully matured, leathery leaves.

\section{How to make a T-bud}

T-budding (see fig. 1) is generally the best budding method for citrus and avocados.

To make a T-bud, make a T-shaped cut on the rootstock about 8 to 12 inches (20 to $30 \mathrm{~cm}$ ) above the ground (fig. 1A). The vertical part of the T should be about 1 inch $(2.5 \mathrm{~cm})$ long and the horizontal part about one-third of the distance around the rootstock. Twist the knife gently to open flaps of bark. Avoid cutting through any buds on the bark of the rootstock.

On the scion (fig. 1B), cut a selected bud beginning about $1 / 2$ inch $(1.2 \mathrm{~cm})$ below the bud and ending about $3 / 4$ to 1 inch (1.9 to $2.5 \mathrm{~cm}$ ) beyond the bud. Make a horizontal cut about $3 / 4$ inch $(1.9 \mathrm{~cm})$ above the bud down through the bark and into the wood. Gently remove the shieldshaped piece for budding (fig. 1C).

Slip the budwood down into the T-shaped cut under the two flaps of bark until the horizontal cuts of the bud match up with the horizontal cut of the $\mathrm{T}$

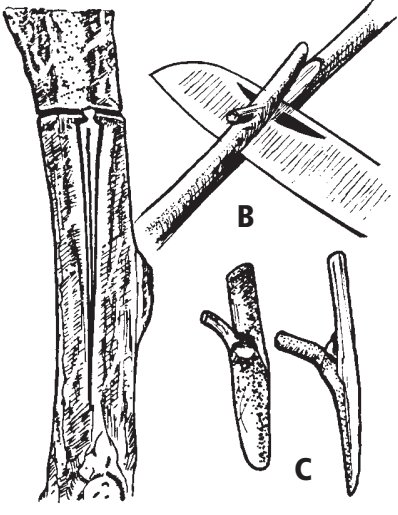

A

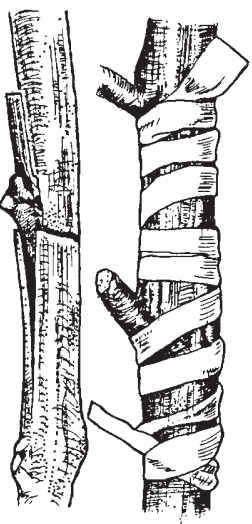

D

E
Figure 1. T-budding. $\boldsymbol{A}$. Rootstock with T-shaped cut. $\boldsymbol{B}$. Cutting bud from budwood. C. Buds ready for insertion. $\boldsymbol{D}$. Bud inserted into the cut. $\boldsymbol{E}$. Graft wrapped with budding rubber. 
(fig. 1D). After inserting the budwood into the rootstock, wrap the bud and rootstock with budding rubber (fig. 1E) Budding rubber is available from agricultural supply or hardware stores; if budding rubber is unavailable, use wide rubber bands, green tie tape, or stretchy tape. Leave the bud exposed while wrapping. Do not coat the area with grafting wax or sealant.

If the budding is done in the fall, the buds should be healed in about 6 to 8 weeks; in the spring, healing should take about 3 to 4 weeks. After the bud has healed, unwrap it and cut off the remaining shoots or stock about 12 to 14 inches (30 to $35 \mathrm{~cm}$ ) above the bud union. This will

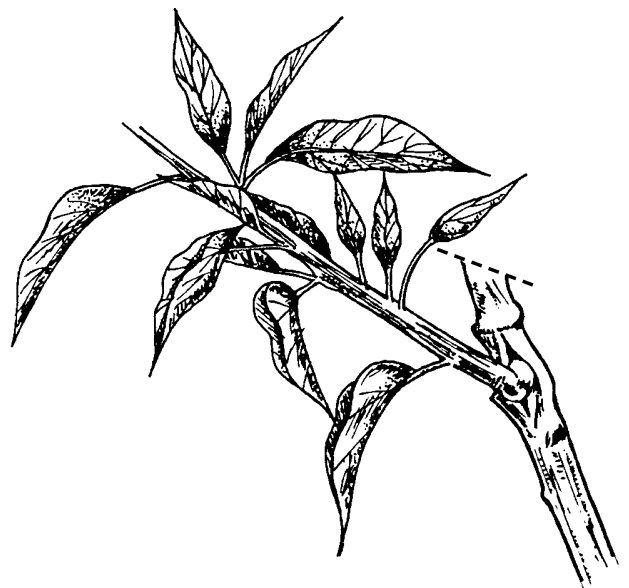

Figure 2. After T-bud begins to grow, remove nurse branch just above the bud.

be the nurse branch, which helps protect the new bud union. After the budwood has grown a few new leaves, completely remove the nurse branch to about $1 / 8$ inch (3 $\mathrm{mm}$ ) above the bud union (fig. 2).

\section{G R AF T I N G}

\section{Whip grafting}

The best grafting technique for small-diameter ( $1 / 4$ to $1 / 2$ inch [0.6 to $1.2 \mathrm{~cm}])$ rootstocks is whip grafting. Whip grafting should be done in the fall or spring. Although whip grafts use more scion wood than budding does, they allow the grafted plant to develop more rapidly.

To make a whip graft (fig. 3), select as a scion hard and mature green wood. First make a long, sloping cut about 1 to $2 \frac{1}{2}$ inches $(2.5$ to $6.2 \mathrm{~cm})$ long on the rootstock

Figure 3. Whip grafting. A. Rootstock stem cut for grafting. $\boldsymbol{B}$. Tongue cut into rootstock to hold scion in place. $\boldsymbol{C}$. Scion cut for grafting, with tongue. D. Scion and rootstock properly aligned. E. Graft wrapped with budding rubber.

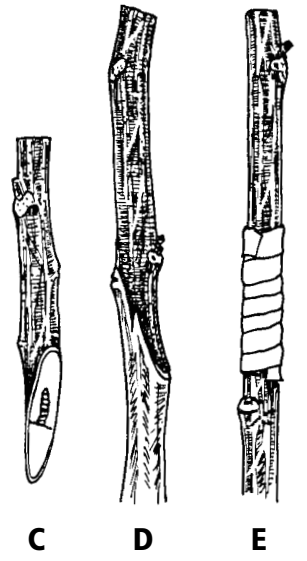
(fig. 3A). Make a matching cut on the scion. Cut a "tongue" on both the scion and rootstock by slicing downward into into the wood (figs. 3B-3C). The tongues should allow the scion and rootstock to lock together. Fit the scion to the rootstock (fig. 3D) and secure with budding rubber (fig. 3E). Apply grafting wax to seal the union. To prevent sunburn, new whip grafts should be protected from the sun until they heal. After the scion has begun to grow, remove any growth from the rootstock. If necessary, support new shoots by staking.

\section{Bark grafting}

The best grafting technique for large-diameter trees or branches is bark grafting (fig. 4). To make a bark graft, first cut off the rootstock (the trunk or branch to be grafted) just above a crotch where smaller branches sprout out. If possible, try to retain one branch of the original plant as a nurse branch. The nurse branch will provide the scion nutrition and support from wind (the nurse branch will eventually be removed). 
Figure 4. Bark grafting. A-C. Scions cut for bark grafting. $\boldsymbol{D}$. Scions in proper position (note flathead nail).
Cut vertical slits $2^{1 / 2}$ to $3 \frac{1}{2}$ inches $(6.2$ to $8.7 \mathrm{~cm}$ ) long through the bark of the remaining freshly cut rootstock stubs down to the wood. These slits should be spaced 3 to 5 inches ( 7.5 to $12.5 \mathrm{~cm}$ ) apart. Cut the scions 5 to 6 inches ( 12.5 to 15 $\mathrm{cm}$ ) long with 4 to 6 buds per scion (figs. 4A-4C). If scions are cut longer than this, they may dry out before healing. When cutting the scions, make a sloping cut about 3 inches $(7.5 \mathrm{~cm})$ long at the base of the scion.

Using a grafting knife or other very sharp knife, lift the bark on one side of the slit. Insert the scion into the slit with the long-cut surface of the scion facing the wood of the rootstock and push it down into the slit (fig. 4D). Make sure that the scion fits snugly into the slits in the bark and that the cambiums are properly aligned.

Secure citrus scions by nailing them in place with thin flathead nails or tying them with strong cord or tree tape. Secure avocado scions with plastic nursery tape. Coat all cut surfaces thoroughly, including the tops of the scions, with grafting wax or pruning paint. To protect the graft from sunburn, paint it with white interior water-based paint, either undiluted or mixed 50/50 with water. Paint the entire area

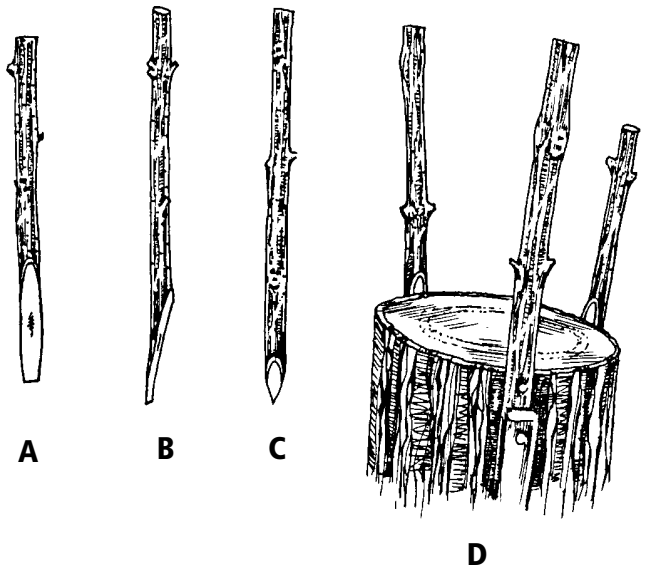
around the graft union, including the scions, waxed areas, and the exposed trunk below the graft union. Inspect the grafts frequently and rewax them if they begin to crack or dry out.

Once the scions begin to grow well, remove all but one scion per branch. Early on, however, prune the scions that will be removed to reduce their vigor but do not prune the scion that will be kept. The one scion you keep will eventually become a main scaffold branch. Any nurse branches should also be removed after all the scions are growing well.

\section{TOP WORKING}

Top working is the process of changing fruit varieties on a mature tree. Most citrus and avocado are top worked by bark grafting (see above). Top working should be done in the spring or fall. 


\section{FURTHER READING}

Garner, R. J., and S. A. Chaudri. 1976. The propagation of tropical fruit trees. East Malling, Kent, England: Commonwealth Bureau of Horticulture and Plantation Crops, Horticultural Review No. 4.

Hartmann, H. T., and J. A. Beutel. 1994. Propagation of temperate-zone fruit plants. Oakland: University of California Division of Agriculture and Natural Resources Publication 21103.

Hartmann, H. T., and D. E. Kester. 1975, Plant propagation: Principles and practices. 3rd ed. Engelwood Cliffs, N.J.: Prentice-Hall.

Reuther, Walter. 1973. The citrus industry. Vol. 3. Oakland: University of California Division of Agriculture Sciences.

Whitsell, R. H., G. E. Martin, B. O. Bergh, A. V. Lypps, and W. H. Brokan. 1989. Propagating avocados: Principles and techniques of nursery and field grafting. Oakland: University of California Division of Agriculture and Natural Resources Publication 21461.

Tasaki, Ernia. 1985. All about citrus and subtropical fruits. San Ramon, CA: Ortho Books

The author would like to thank Raul Gonzalas, Lindcove Research \& Extension Center, for assistance with this publication.

An electronic version of this publication is available on the DANR Communication Services website at http://danrcS.ucdavis.edu.

\section{Publication 8001}

(C)1997 by the Regents of the University of California, Division of Agriculture and Natural Resources.

The University of California, in accordance with applicable Federal and State law and University policy, does not discriminate on the basis of race, color, national origin, religion, sex, disability, age, medical condition (cancer-related), ancestry, marital status, citizenship, sexual orientation, or status as a Vietnam-era veteran or special disabled veteran. The University also prohibits sexual harassment.

Inquiries regarding the University's nondiscrimination policies may be directed to the Affirmative Action Director, University of California, Agriculture and Natural Resources, 300 Lakeside Drive, 6th Floor, Oakland, CA 94612-3560; (510) 987-0096. 